\title{
麦類に含まれる食物緘維の栄養生理学的研究
}

\author{
青 江 誠一郎 \\ 大妻女子大学家政学部食物学科
}

\section{Nutritional and Physiological Effects of Dietary Fiber in Oats and Barley}

\author{
Seiichiro Aoe \\ Department of Food Science, Faculty of Home Economics, Otsuma Women's University
}

Oats and barley are rich in water-soluble dietary fiber which is mainly composed of $\beta$-glucan. This study evaluates the nutritional and physiological effects of the water-soluble dietary fiber, cereal gum, in oats and barley from animal and human experiments.

\section{Effect of the water-soluble dietary fiber in oats and barley on the lipid metabolism in rats}

The effects of ingested oat and barley gum on the plasma and liver lipid levels were examined in genetically obese and lean Zucker rats. Obese and lean male Zucker rats, aged 6 weeks, were fed for 34 days on a standard diet or on diets corresponding to $2 \%$ total dietary fiber. Both the oat and barley gum suppressed the liver lipid accumulation and elevation of the plasma cholesterol level in obese rats. The results of this animal experiment indicate that ingested oat and barley gum ameliorated fatty liver and hypercholesterolemia in obese Zucker rats.

\section{Effects of oat and barley gum on the lipid metabolism in rats}

The effect of various amounts of oat and barley gum added to the diet on the plasma and liver lipid levels was examined in cholesterol-fed rats. Male Sprague-Dawley rats, aged 5 weeks, were fed for 9 days on a diet containing the oat or barley gum corresponding to $\%, 1 \%, 2 \%$, or $4 \%$ soluble fiber. The plasma triglyceride, liver cholesterol, and liver triglyceride levels were lower in the rats fed on the diets containing $1-4 \%$ oat gum and $2-4 \%$ barley gum than in the rats fed on the gum-free diet. The diet containing $4 \%$ oat gum increased the fecal excretion of total lipids. The fecal excretion of acidic steroids was higher from the rats fed on the diets containing $2-4 \%$ oat gum and $1 \%$ barley gum than from the rats fed on the gum-free diet. The results of this experiment indicate that the minimum amounts of oat and barley gum, which acted as lipid-lowering compounds, were respectively $1 \%$ and $2 \%$ of fiber in the diet.

Effect of oatmeal supplementation on the serum cholesterol levels in men with boundary and mild hypercholesterolemia

We examined the effect of oatmeal containing $\beta$-glucan on blood lipids and the safety of its long-term intake in men with boundary and hypercholesterolemia. A total of 48 men with boundary and mild hypercholesterolemia were assigned to three groups. Each group A subject was given four pieces of placebo cookies once a day for 12 weeks, each group B subject was given test oatmeal cookies containing oatmeal at $30 \mathrm{~g} / 4$ pieces, and each group C subject was given the same cookies containing oatmeal at $45 \mathrm{~g} / 4$ pieces. The serum total cholesterol level for group $\mathrm{C}$ with boundary hypercholesterolemia was significantly lower than that for group A or group C $(p<0.05)$. The results of this human trial indicate that supplementation with oatmeal at $45 \mathrm{~g} / \mathrm{day}$ (1.6g of $\beta$-glucan/day) decreased the serum total cholesterol level in men with boundary hypercholesterolemia.

Additional human trial with oatmeal porridge

An additional human trial with oatmeal porridge was examined; each subject in the oatmeal group was given oatmeal porridge containing 45g of oatmeal (1.6g of $\beta$-glucan) once a day for 12 weeks, and the control group subjects were given control porridge containing white rice and cellulose as the substitute for oatmeal. The level of serum total cholesterol in the oatmeal group was significantly lower than that in the control group throughout the ingestion period $(p<0.05)$. This additional human trial indicates that oatmeal containing $\beta$-glucan could modulate the

本論文は，平成 19 年度（第 54 回日本栄養改善学会学術総会）学会賞受賞対象の研究である。

(連絡先：青江誠一郎 $\bar{T} 102-8357$ 千代田区三番町 12 大妻女子大学家政学部食物学科 電話·FAX 03-5275-6048

E-mail s-aoe@otsuma.ac.jp) 
level of serum total cholesterol.

Effect of oatmeal supplementation on the serum cholesterol levels in adults with boundary and mild hypercholesterolemia

This study examined the effect of oatmeal on the serum cholesterol levels in Japanese adult men and women with boundary and mild hypercholesterolemia. Seventy-four men and nineteen women were randomly assigned to either the placebo or oatmeal group for 12 weeks of treatment. The oatmeal group was given daily oatmeal porridge containing $60 \mathrm{~g}$ of oatmeal ( $2.1 \mathrm{~g}$ of $\beta$-glucan), and the placebo group was given porridge containing white rice and cellulose as the substitute for oatmeal. The serum total cholesterol level for the oatmeal group was significantly lower throughout the supplementation period $(p<0.05)$ than for the placebo group, the same effect also being observed in the non-HDL cholesterol levels. This human trial indicates that supplementation with oatmeal at $60 \mathrm{~g} /$ day (2.1g of $\beta$-glucan/day) was the optimal dosage and safely decreased the serum cholesterol levels in Japanese adults with boundary and mild hypercholesterolemia.

These results indicate the nutritional importance of formulating a diet containing oats or barley in order to optimize health and counteract the risk factors for metabolic syndrome in an aging population.

Jpn. J. Nutr. Diet., 66 (6) $311 \sim 319$ (2008)

\section{I，研究の背景}

NCEP (National Cholesterol Education Program) やWHO (世界保健機構) が, メタボリックシンドロー ムという病態の概念を発表したことにより注目を集め ている。本症候群は, ただ単なる多数の因子が偶然集 積したものではなく，その上流に内臓脂肪蓄積が成因 基盤として存在することが明らかとなっている。我が 国における診断基準が 2005 年 4 月に策定され，その中 で腹部肥満 (内臓脂肪蓄積) が必須項目として存在し, 高血圧, 脂質代謝異常, 高血糖のうち 2 項目以上の因 子が当てはまる場合をメタボリックシンドロームと診 断することになった。メタボリックシンドロームが強 い動脈硬化の成因基盤となることから, 死因の $1 / 3$ を 占める心臓病や脳卒中の予防には, 内臓脂肪蓄積の抑 制ならびに高血圧, 脂質代謝異常, 高血糖の改善が必 要である。

そのような背景の中, 改めて食物繊維の役割に大き な関心が集まっている。食物繊維とは, 「人の消化酵素 によって消化されない食物中の難消化性成分の総体」 のことをいう。食物繊維の分類法は様々であるが, 水 溶性と不溶性, 発酵性と非発酵性などの性質に分類さ れる。近年では，レジスタントスターチと呼ばれる消 化酵素に抵抗性のデンプンや様々な重合度の難消化性 オリゴ糖も含めるため, 栄養生理作用を論ずるには性 質や組成の詳細が求められる。

日本人の食物繊維摂取量は戦後直後には現在推奨さ れている目標摂取量をほぼ攝取していたが，その後, 特に高度経済成長期における食生活の変化に伴って大 幅に低下した。平成 17 年国民健康・栄養調査報告によ ると, 現在の日本人の平均的な食物緎維摂取量は 1 日 $15.2 \mathrm{~g}$ であり ${ }^{1)}$ ，欧米諸国と比べて高いとはいえない。
食物瀻維摂取量低下の原因は, 穀物からの摂取の減少 によるところが大きい2)。すなわち，穀物摂取量の低下， 精白度の向上, 雑穀類消費の低下などが原因となって いる。

本研究では, 穀物の中で可食部に食物繊維が多く含 まれる麦類に着目した。特に, オーツ (燕麦) と大麦 は他の穀物に比べて， $\beta$-グルカンを主体とする水溶性 食物瀻維を多く含む点に特徵がある。オートミールは ミネラルや食物瀻維が豊富なオーツを調理して乾燥さ せた食品で, 水や牛乳とともに加熱し，適宜味付けを行 って和状にして食べられている。オートミールは，欧米 では, コレステロール低下作用をもつ食品として，既に 多くの研究がなされている。また, その生理効果の主体 は, 水溶性食物繊維の一種である $\beta$-グルカンであると 推定されている。1997 年には心疾患のリスク低減のヘル スクレームが, 米国食品医薬品局（FDA）により許可 されている。しかし，オートミールまたはオートミール 由来の $\beta$-グルカンの血清コレステロール值への影響を 調べた報告は, 欧米人を対象とした例が多く,オートミ ールまたは $\beta$-グルカンが, 日本人の血清コレステロー ル值に及ぼす影響を調べた報告はわずかである。

大麦の有効性については, かつて柳沢ら ${ }^{3)}$ が糖尿病 患者に摂取させると, 血糖值の上昇が精白米に比べて 緩慢になることを示した。その後, 佐藤ら ${ }^{4)}$ も同様の 実験を行い，大麦摄取後の血糖值と血中インスリンの 上昇が特に糖尿病患者で顕著に抑制されることを明ら

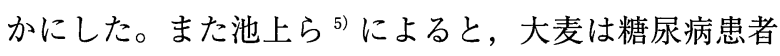
の治療食として用いた場合に, 糖代謝の改善が期待さ れることを示した。FDA は, オーツ又はオオバコから の水溶性食物瀻維の摂取が心臟病の危険因子を減らす かもしれないというヘルスクレームを許可したが, 
2006 年になって大麦も同様の作用があることを認めた。

このような研究背景の中で, 麦類の食物繊維の水溶 性画分（ガム質）に着目し，長年にわたり基礎研究を

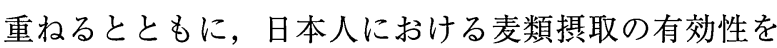
検討してきたのでここに紹介したい。

\section{II. オーツ, 大麦中の水溶性食物繊維が ラットの脂質代謝に及ぼす影響}

オーツならびに大麦中の $\beta$-グルカンの効果を検証す る目的で動物実験を行った。オーツならびに大麦から ガム質画分を抽出・精製し，遺伝性肥満 Zucker ラット (obese ラット) ならびに同系で肥満を生じない正常ラ ット（leanラット）に㠌取させて，脂質代謝に及ぼす 影響について比較した ${ }^{6}$ 。調製したオーツガム質ならび に大麦ガム質の分析の結果，それらは非デンプン性の グルカンで構成されていた（表 1)。両者の比較をする と，オーツガム質の方が，大麦ガム質よりも $\beta$-グルカ ン含量が高いことが推定された。一方，大麦がム質は， アラビノースとキシロースからなるアラビノキシラン を比較的多く含んでいることが認められた。

表 1 大麦㧍よびオーツガム質の組成（\%)

\begin{tabular}{lcc}
\hline & 大麦ガム質 & オーツガム質 \\
\hline タンパク質 & 8.0 & 4.7 \\
灰分 & 8.8 & 9.7 \\
総食物繊維 & 66.8 & 67.7 \\
グルース & 38.4 & 60.5 \\
アラビノース & 11.6 & 3.9 \\
キシロース & 16.8 & 3.3 \\
\hline
\end{tabular}

〈肝臟コレステロール蓄積量〉

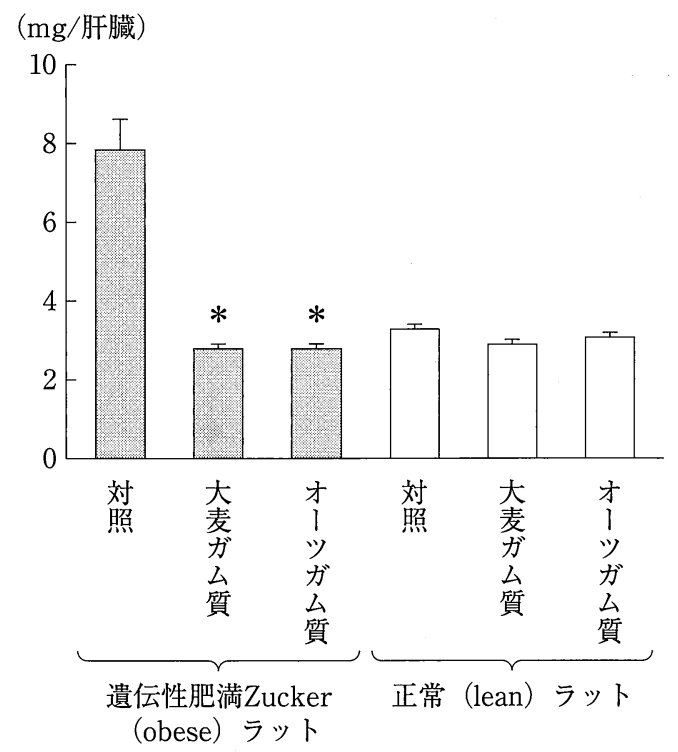

動物実験の結果，標準飼料を摂取させた遺伝性肥満 Zucker ラットは, 正常ラットに比べて, 高脂血症なら びに肝臓の肥大および脂質蓄積, 腹腔内脂肪の蓄積が 観察された。オーツガム質ならびに大麦ガム質を摂取 させた遺伝性肥満 Zucker ラットは，正常ラットに比べ て, 肝蔵中の脂質蓄積（図 1), ならびに血漿総コレス テロール濃度の上昇（図 2 ; オーツガム質のみ有意差 を検出）をそれぞれ抑制した。各ガム質が正常ラット の血漿総ならびに肝臟脂質濃度に及ぼす影響は，遺伝 性肥満 Zucker ラットよりも小さかった。このことょり， オーツガム質ならびに大麦ガム質は, 遺伝性肥満 Zucker ラットの脂肪肝の発生ならびに血漿総コレステ ロール濃度の上昇を抑制するなどの，肥満に伴う症状 を緩和することが認められた。

次に, ラットの脂質代謝改善に有効な穀物ガム質の 最少食物繊維添加量をオーツと大麦で比較するために, オーツならびに大麦からガム質を抽出・精製して, 高 コレステロール飼料に食物纎維として $1 ， 2 ， 4 \%$ の 3 水準添加し, SD ラットに摂取させて, 各ガム質添加群 の血槳および肝臟脂質に及ぼす影響をガム質無添加群 (0％群）と比較した7)。その結果，オーツガム質を $1 \%$ 以上添加した群と大麦ガム質を $2 \%$ 以上添加した群 は，血漿トリグリセリド濃度（図 3), 肝臓コレステロ ール，肝臟トリグリセリド蓄積量（図 4）を低下させた。 出納試験の結果，オーツガム質 $4 \%$ 群は，総脂質の排 泄量が有意に多かったが，大麦ガム質では有意差が検 出されなかった。オーツガム質を $2 \%$ 以上添加した群 と大麦ガム質を $1 \%$ 以上添加した群は，糞中への胆汁

〈肝臓トリグリセリド蓄積量〉

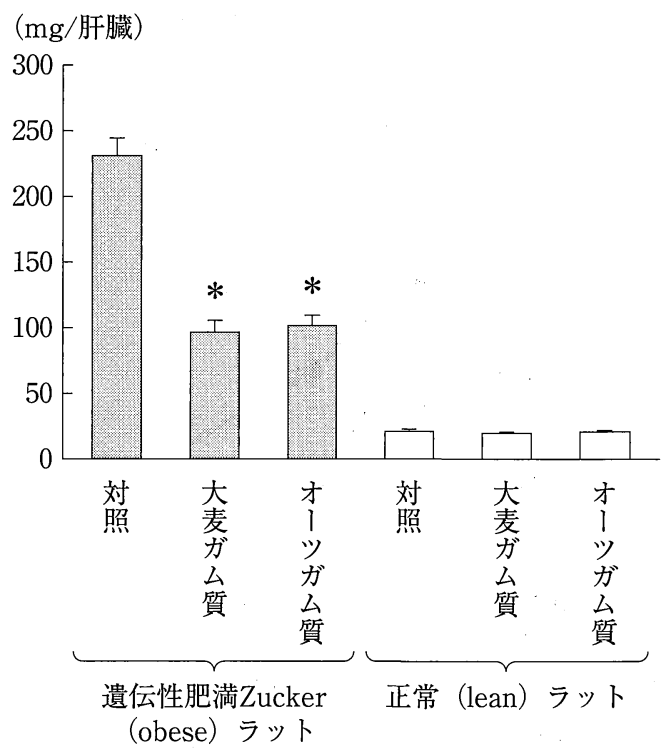

図 1 大麦，オーツのガム質画分が遺伝性肥満Zuckerラットの肝臓脂質蓄積に及ぼす影響 エラーバーは標準偏差を表す。

*対照群と比べて有意差あり $(p<0.05)$ 。 
酸排泄量が増加した。一方, 中性ステロールの排泄促 進作用は認められなかった。以上の結果, コレステロ ール撖取ラットの脂質代謝を改善する穀物ガム質の最 少食物緎維添加量は，オーツガム質では $1 \%$, 大麦ガ ム質では $2 \%$ と推定した。両穀物の有効量の差は, 調 製したガム質の $\beta$-グルカン量によるものと考えられる。 これらの作用は胆汁酸代謝を介したものと推定された が，全てのメカニズムが解明されてはいない。さらに， オーツと大麦の食物繊維の不溶性画分と水溶性画分を それぞれ調製し，ラットを用いた同様の実験を行った結

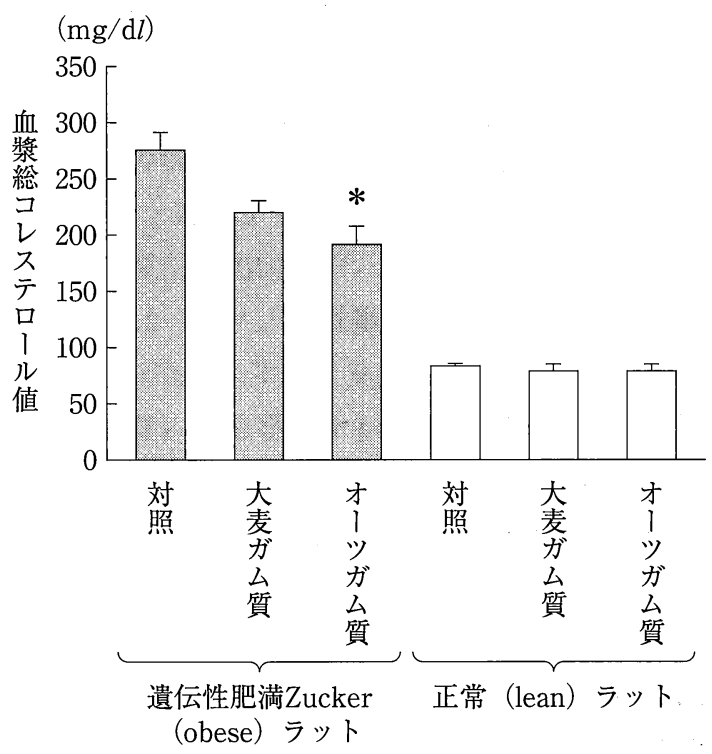

図 2 大麦，オーツのガム質画分が遺伝性肥満Zucker ラットの血漿総コレステロール濃度に及ぼす影響 エラーバーは標準偏差を表す。

*対照群と比べて有意差あり $(p<0.05)$ 。

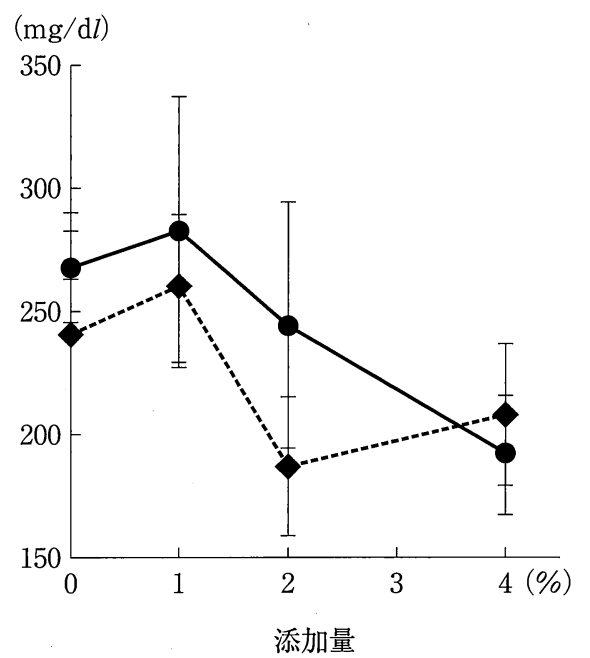

〈血槳トリグリセリド濃度〉

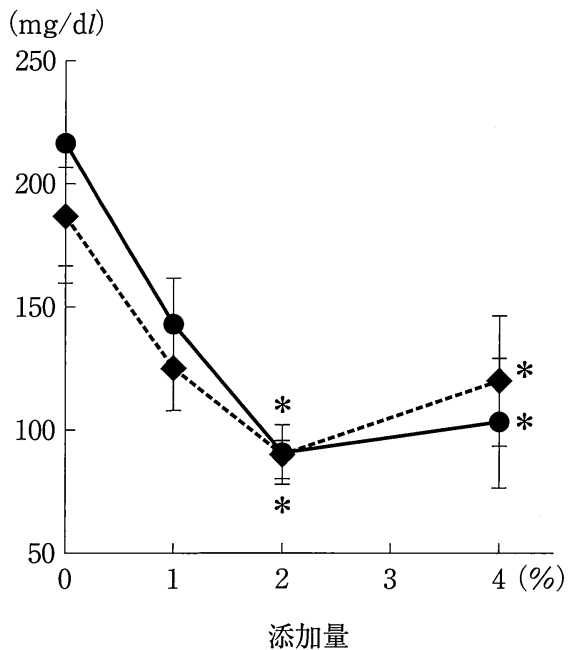

図 3 大麦，オーツのガム質画分がコレステロール負荷ラットの血漿脂質濃度に及ぼす影響

大麦ガム質添加群

エラーバー標準偏差を表す。

*0\%群と比べて有意差あり $(p<0.05)$ 。 
〈肝臓コレステロール蓄積量〉

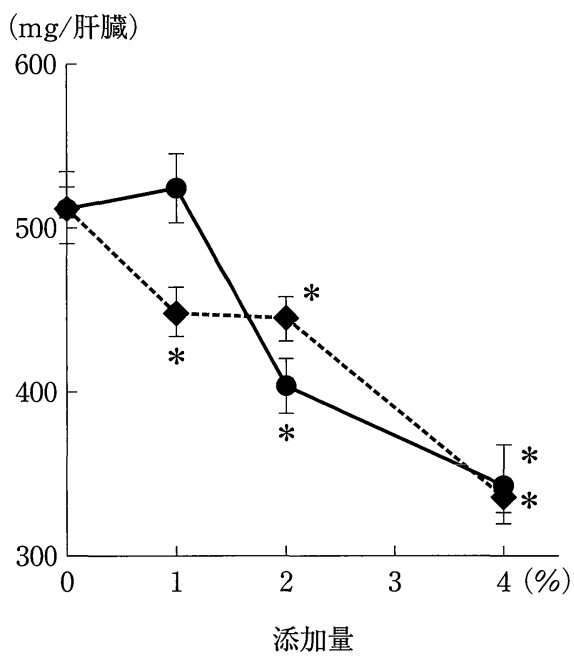

$\langle$ 肝臟トリグリセリド蓄積量〉

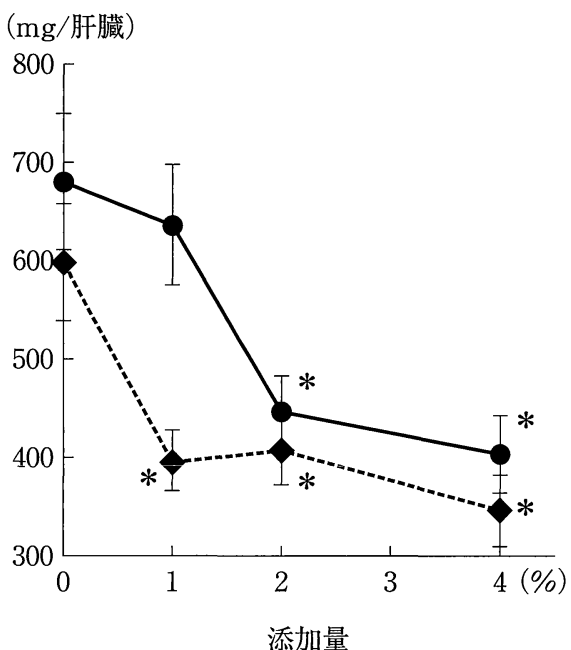

図 4 大麦，オーツのガム質画分がコレステロール負荷ラットの肝臓脂質蓄積に及ぼす影響

大麦ガム質添加群

エラーバーは標準偏差を表す。

*0\%群と比べて有意差あり $(p<0.05)$ 。

与えることを標榜する食品の撕取を原則として禁止し た以外，日常生活については変えることのないよう指 示し，非日常的な暴领暴食を避けるよう指導を行った。 摂取 12 週間後の観察期間は 4 週間とした。

観察期間前 (観察前), 観察後の摂取期間直前（撖取 前), 摂取 4 週間後, 摄取 8 週間後, 摂取 12 週間後, 摂取 12 週間後の観察期間後（観察後）の 6 回, 血液検 查を実施した。摄取 $4 ， 8 ， 12$ 週間後の検查は，翌週の 1 週間以内に検查を行うこととした。血液検查は, 一般 的な血球成分，血清脂質，血清生化学分析を行った。 また, 観察前, 摄取前, 摂取 4 週間後, 拱取 8 週間後, 摂取 12 週間後, 観察後の 6 回, 体重, BMI, 体脂肪率, 腹囲の測定を行った。試験期間中の食事による栄盖素 摂取量については，各検査直前の 3 日間の食事記録に ついて，五訂増補日本食品標準成分表（以下，五訂增 補食品成分表）に基づき管理栄養士により栄養素等搨 取量を計算した。また，運動量については万歩計によ り，検查前 3 日間の運動量を測定した。

\section{2. 実験結果の概要}

摄取前および摄取期間中の飲食による1日あたりの 総摂取エネルギー量, タンパク質, 脂質, 炭水化物, コレステロール摂取量において，群間に有意な差を認 めなかった。一方, 食物繊維摂取量は, オートミール $45 \mathrm{~g}$ 配合群において，摂取期間中プラセボ群に比べて有 意に食物瀻維掑取量が増加した。各群とも食物瀻維負 荷の影響を除いてクッキー 4 枚を摂取したときの栄養 素等摂取量の前後で大きな変動は認められず，コント ロールされた食生活において試験が実施されたことが 確認された。万歩計を用いた運動量の測定でも，群間

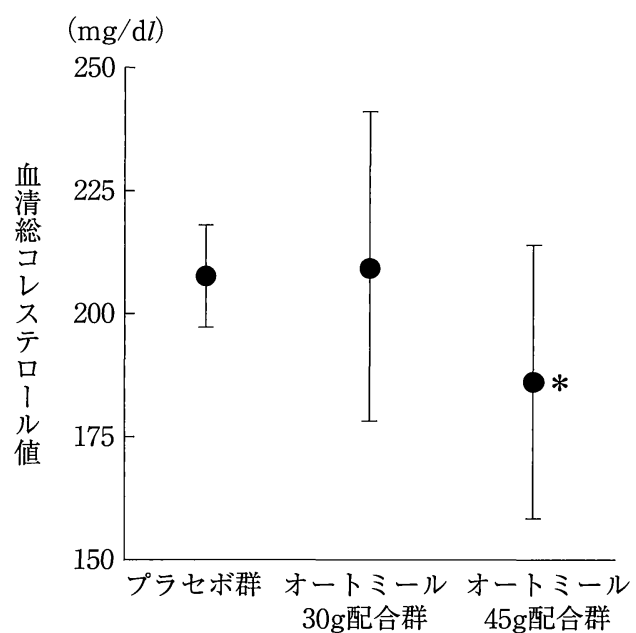

図 5 摂取 12 週間後の境界域層の血清総コレス テロール值

エラーバーは標準偏差を表す。

*プラセボ群と比べて有意差あり（ $p<0.05 ）$ 。

あるいは各期間において有意な差を認めなかった。

血清総コレステロール值は, 境界域（総コレステロ ール值が $180 \sim 219 \mathrm{mg} / \mathrm{d} l$ ) と軽度高コレステロール血 症（総コレステロール值が $220 ２ 60 \mathrm{mg} / \mathrm{d} l$ ) の二層に 分かれたため, 解析は層別に行った。その結果, オー トミール $45 \mathrm{~g}$ 配合群では，境界域層において，摄取前 の血清総コレステロール值の平均が $206 \mathrm{mg} / \mathrm{d} l$ から摄取 12 週間後 $186 \mathrm{mg} / \mathrm{d} l$ と低下し，境界域層におけるプラ セボ群とオートミール $45 \mathrm{~g}$ 配合群との間に有意な差を 認めた $(p<0.05$, 図 5)。しかしながら, オートミー ル $45 \mathrm{~g}$ 配合群の軽度高コレステロール血症層では有意 な変動は認められなかった。HDL コレステロール值と 


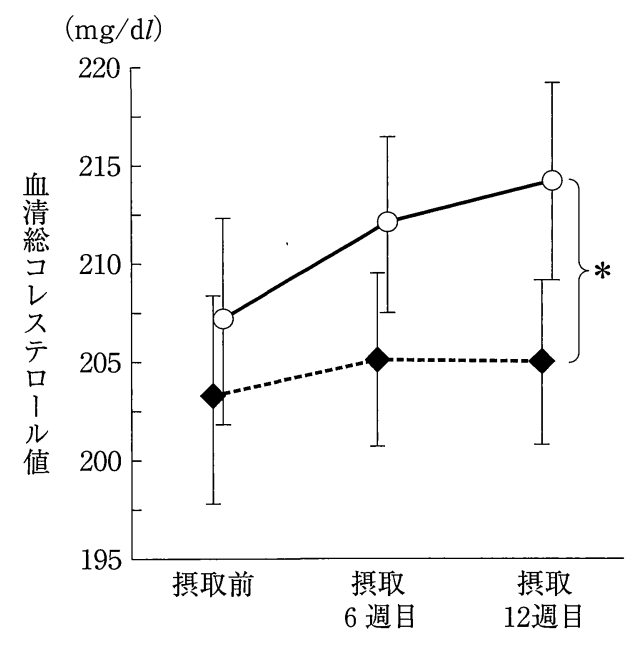

図 6 血清総コレステロール值の推移

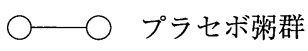

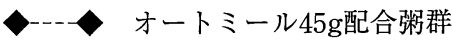

エラーバーは標準偏差を表す。

*プラセボ咧群と比べて摂取期間中有意差あり（反復 測定デー夕解析 ; $p<0.05)$ 。

トリグリセリド值は，全期間を通じて各群とも有意な 変動は認められなかった。なお， 12 週間の摂取期間中, 本試験品によると思われる副次作用の発現は，一切認 められなかった。

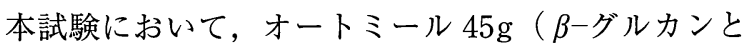
して $1.6 \mathrm{~g})$ を含有するクッキーは, 摂取 12 週間後にお いて境界域の被験者の血清総コレステロール值を低下 させた。オートミールの有効摂取量を調べた本成績は, 日本人の試験成績でははじめての成績と考光られる。 しかしながら, 軽度高コレステロール血症層では効果 が確認できなかったこと等から, 被験者の背景因子を さらに考慮した追試験が必要と考えられた。

\section{3. 追試験}

クッキーを用いた試験結果より，オートミール摂取 の有効性について，オートミール $45 \mathrm{~g}$ （ $\beta$-グルカンと して $1.6 \mathrm{~g}$ ）摂取の有効性を調べることとした。オート ミールの調理法にはクッキーなどの焼き菓子とするほ かに, ポリッジ（牛乳と砂糖を用いた柅）が知られて いるが，日本人の食生活を考慮して，好みの味付けが 可能なレトルト啉の形態で摂取する試験を追試験とし て実施した。被験者は, 血清総コレステロール値 177 $\sim 263 \mathrm{mg} / \mathrm{d} l$ の日本人男性 36 名とした。二重盲検法に より 1 群 18 名の 2 群に分け, オートミール $45 \mathrm{~g}$ を含む レトルト粥または，セルロースを配合して食物繊維量 を同一にした白米を含むレトルト弱を 1 日 1 食ずつ 12 週間㠌取させた。

その結果, 図 6 に示すように, 摂取期間中, オート ミール 45g 配合粥群の血清総コレステロール值はプラ
セボ柅群に比較し，有意に低い值を示した $(p<0.05)$ 。 その他の生理学的検查, 生化学検査, 自覚症状の検查 結果から，オートミール摂取による異常は認められな かった。オートミール $45 \mathrm{~g}$ の撖取は, 日本人の血清総 コレステロール值に影響を及ぼす下限值であると考え られた。なお, 米国人において, 血清総コレステロー 儿濃度を低下させる量は， $\beta$-グルカンとして $3 \mathrm{~g}$ 以上と 報告されている ${ }^{11) 。}$

\section{$N$ : オーツを含む粥の摄取が境界域および 軽度高コレステロール血症者の 血清総コレステロール值に及ぼす影響 ${ }^{12)}$}

\section{1. 実験の概要}

前述の試験結果より，有効性を詳細に調べるために 摄食可能な範囲に扔いてオーツの摂食量を増量し, 被 験者数を増やした実験を行った。健康な日常生活を営 む者の中から $20 \sim 64$ 歳の男性 80 名, 女性 20 名を募 集した。試験開始前の検査で総コレステロール值が $200 \mathrm{mg} / \mathrm{d} l$ 以上 $260 \mathrm{mg} / \mathrm{d} l$ 未満かつ LDL コレステロー ル值が $120 \mathrm{mg} / \mathrm{d} l$ 以上 $180 \mathrm{mg} / \mathrm{d} l$ 未満の範囲の者を選択 した。試験開始にあたり選択された被験者は 102 名で あった。試験に直接参加しないコントローラが, 被験 者背景において 2 群（プラセボ群，オートミール群） に差のないよう無作為に割り付けた。脱落基準に従い 今回, 検討の対象となった有効対象者数は男性 74 名, 女性 19 名であった。各群間で，年齢，体重，BMI，血 清脂質検查において有意な差を認めなかった。試験の 実施に際しては, 治験審查委員会の承認のもとに行わ れ，ヘルシンキ宣言に従い，被験者に対しては研究内 容，方法などについて医師より十分な説明を行い文書 による同意を得て実施した。

本試験では，オートミール $60 \mathrm{~g}$ 配合敫（ $\beta-$ グルカン 2.1g）を試験食とした。一方，プラセボ食は，オートミ 一ルの代わりに白米を用い，食物瀻維量を同一にする ためにセルロースを配合した。また，食感ならびに外 観を区別できなくするために少量の加工デンプン，お よびカラメル色素を配合して調製した。摂取前に 2 週 間の観察期間の後, プラセボ群，オートミール群には,

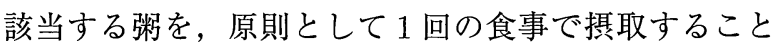
とし，分割して摄取した場合もしくは残食した場合に はその旨を食事記録に記載するように指導した。試験 食品の撖取にあたっては，被験者に対して，オートミ 一ル食またはプラセボ食に約 $300 \mathrm{~m} l$ のお湯を加え 2,3 分間蒸らした後に食するように指導した。なお，予め 両試験群の被験者に粉末スープを配布し，好みに応じ て使用してもらった。被験者には試験期間中, 試験用 に提供された試験食以外に血清脂質値に影響を与える 


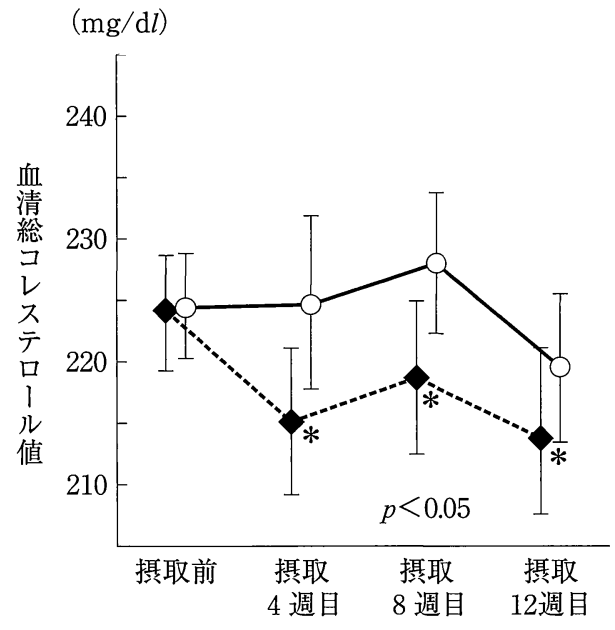

図 7 血清総コレステロール值の推移 ○一プラセボ群・ー-・オートミール群 エラーバーは95\%信頼区間を表す。

${ }^{*} 4$ 〜2週目においてプラセボ群と有意差あり（反復 測定デー夕解析 $; p<0.05)$ 。

ことを標榜する食品の摂取を原則として禁止した以外， 日常生活については変えることのないよう指示し, 非 日常的な暴飲暴食を避けるよう指導を行った。摂取終 了後の観察期間は 4 週間とした。今回, 被験者に対し ては，コントローラが試験食の割付管理を行い，被験 者および検查に参加する医師・医療関係者には，いず れの試験食であるかの情報は提供されなかった。

摄取直前 (摂取前), 摄取 4 週間後, 摂取 8 週間後, 摂取 12 週間後, 摄取後の観察期間後（観察後）の 5 回, 血液検查を実施した。血清脂質検查, 血球成分と生化 学検査を行った。また,レムナント様リポタンパク (RLP) -コレステロール，アポリポタンパク（A-I， $\mathrm{A}-\mathrm{II}, \mathrm{B}, \mathrm{C}-\mathrm{II}, \mathrm{C}-\mathrm{II}, \mathrm{E})$, リポタンパク (a)，イ ンスリンは摄取前後のみ測定した。試験期間中の食事 による栄養素等摄取量については, 各検査直前の 3 日 間の食事記録について，五訂増補食品成分表に基づき 管理栄盖士により計算した。また，運動量については 万歩計により，検査前 3 日間の運動量を測定した。

\section{2. 実験結果の概要}

摂取前および摄取期間中の飲食による1日あたりの 総摄取エネルギー量, タンパク質, 脂質, 炭水化物, コレステロール，食物繊維摂取量に扔いて，群間に有 意な差を認めなかった。万歩計を用いた運動量の測定 は, 群間あるいは摂取前と摂取期間中の比較において 有意な差を認めなかった。試験期間中における血清総 コレステロール值の平均值の推移に関して図 7 に示す。 血清総コレステロール值は, 検定の多重性を考虑して 反復測定デー夕解析を行った結果，摂取期間 $4 \sim 12$ 週 目において時点 $\times$ 群の交互作用が有意とならなかった。
また，性差に有意差が認められなかった。そこで，全 被験者に抒いて群間の平均的な反応の差を検定した結 果, オートミール群がプラセボ群に比べて摂取期間を 通じて有意に低いことが認められた $(p=0.035)$ 。また, 副次的な検定として摂取前值との比較を群ごとに対応 のある $t$-検定により解析した結果, オートミール群に おいて 4 週目, 12 週目で有意な低下, 8 週目では低下 傾向（ $p=0.065 ）$ が認められた。一方，プラセボ群は 摂取前と有意な変動は認められず, 試験期間中に変化 しなかったものと考えられた。non-HDL コレステロ ール值については, オートミール群では血清総コレス テロール值の推移と同様の変化を示し, 摂取前に比べ て 4 週目より有意に低下し, 以後低下作用が 12 週目ま で継続し，観察後に摄取前値と差が認められなくなっ た。血清生化学に関する検查值は，両群とも摄取期間 中，撕取前との比較に扔いて，いずれの変動も一過性 あるいは正常值範囲内の変動であり，個別にみた場合 に扔いても, 肝機能検查值, 腎機能検查值, および電 解質バランスに打いて，異常変動を示した例は認めな かった。12 週間後のアポリポタンパク E值は, オート ミール群がプラセボ群に比べて有意に低かった。摂取 前值との比較では, オートミール群の RLP-コレステ ロール，アポリポタンパク $\mathrm{C}-\mathrm{II}, \mathrm{C}-\mathrm{III}, \mathrm{E}$ 值が有意 に低下した。

本結果より，オートミールとして 1 日あたり $60 \mathrm{~g}, \beta$ ーグルカンとして $2.1 \mathrm{~g}$ の摂取は境界域および軽度高コレ ステロール血症の日本人成人に扔いて効果が期待でき る量であると考えられる。血清総コレステロール值か ら HDL コレステロール值を差し引いた, non-HDL コ レステロール值をみると, 血清総コレステロール值の 推移と類似していた。したがって, 血清総コレステロ ール值の変動は, non-HDL コレステロール值の変動 によるものと考えられる。non-HDL コレステロール は，肝臟で分泌されたVLDL，VLDL がリポタンパク 質リパーゼによって分解された IDL，ならびに肝性卜 リグリセライド分解酵素によりさらに代謝された LDL 中のコレステロールの総体を指す。本結果から, nonHDL コレステロール值は, オートミール群においては 摂取前值に比べて，摂取期間中は有意に低下し，4，8 週目では群間差も認められた。さらに，摂取 12 週目の リポタンパク質画分を比較すると, LDL コレステロー ルや $\beta$ リリポタンパク值に差は認められず，むしろ RLP ーコレステロールならびに RLP-コレステロールと強い 相関を示して変動するアポリポタンパク C-II，C-III， E 值に変動が認められた。RLPーコレステロールは, VLDL やキロミクロンなどのリポタンパク質が，リポタ ンパク質リパーゼによって分解され生じる中間代謝産物 
であり, 先述の non-HDL コレステロール值の変動は, 一部は RLP-コレステロール值の低下を反映した可能性 が考えられる。アポリポタンパク $\mathrm{E} も ，$ キロミクロンや レムナントの量を反映することから, non-HDL コレス テロールの変動と関連していると考えられる。

\section{3. 作用機序について}

オートミールの血清総コレステロール低下作用に関 しては，これまでに多くのヒトを対象とした試験が実 施されている ${ }^{13 \sim 16)}$ 。対象とする被験者によって有効摂 取量には差異があるものの，オートミールに含まれる $\beta$-グルカンがヒトの血清総コレステロール值を低下さ せることに関しては一定の結論が得られていると考え られる ${ }^{11}$ 。有効摂取量が報告によって異なることにつ いては，生活習慣が異なる被験者が参加するため，母 集団の遺伝的な背景, 食習慣, および運動量などが試

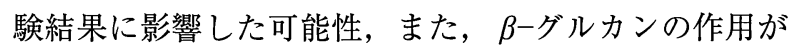
薬物とは異なって穏やかであり，有効性を確認するた めにはかなりの被験者数を確保しなければならないこ となどが考えられる。

オートミールによる血清総コレステロール低下作用 の機序は，食餌性のコレステロールの排泄促進よりは むしろ, 糞便中への胆汁酸の排泄量が増加することに よると考えられている ${ }^{17}{ }^{18)}$ 。胆汁酸の排泄量増加の結 果, 肝臓に扔けるコレステロールから胆汁酸への代謝 が促進されることで肝臓のコレステロールプールが減 少し, 結果として血中へのコレステロールの分泌が減 ることが一因であると推定されている ${ }^{199}$ 。ステロール 類の排泄促進による血清総コレステロール低下作用の 機序は, これまでに報告されているいくつかの水溶性 食物繊維の作用機序と類似する。

\section{V. 今後に向けて}

これまでは，血清総コレステロール低下作用を中心 とした脂質代謝改善作用と麦類の食物繊維掑取の関係 を研究してきたが，今後はメタボリックシンドローム に対する予防効果の主要メカニズムを決めていくこと が重要と考える。これまでに, 我々は麦類の食物緎維 は実験動物において脂質代謝改善作用に加えて脂肪組 織重量や脂肪細胞のサイズに影響を与えることを見出 してきた。さらに，近年の脂質代謝の分子メカニズム 研究から, 内臟脂肪と, 消化管一血管一肝臟が強く連 関しており，これまで考えられてきた食物緎維の消化 管内での直接的な作用のほかにも機能が存在する可能 性も考えられ，さらなる研究が必要である。我々の研 究グループでは， $\beta$-グルカン高含有大麦を用いて, 軽 度高コレステロール血症者を対象にした介入試験結果 を近年報告した ${ }^{200}$ 。大麦が血清 LDL コレステロール值
低下作用を有することに加えて, 内臟脂肪, 腹囲, BMI の低下が認められ, メタボリックシンドロームの 予防効果を有する可能性が期待される。今後, メカニ ズムの解明が急務であり, 麦類のどのような成分ある いは特性が機能発現に寄与しているのかの解明が待た れる。消化管内での作用だけでは説明できない現象も 多く報告されており, 消化管ホルモン応答を介した研 究が重要であろう。特に, インクレチンと総称される GIP（グルコース依存性インスリン分泌刺激ホルモン） と GLP-1（グルカゴン様ペプチド 1）は, 糖尿病をは じめとした糖代謝関連の研究で食物繊維摂取の関係が 報告されている。食物瀻維摂取が消化管ホルモン分泌 に及ぼす影響の詳細については未解明であるが, 脂肪 細胞への作用, インスリン応答の調節などは, 消化管 ホルモンの分泌調節により説明できるかもしれない。

本研究結果は, 日本人の男女に扔いても麦類由来の 食物緎維摂取の有効性を裹付けた結果となった。今後 脂質代謝のみならず，内臓脂肪型肥満を原因とするメ タボリックシンドロームの予防に向けた研究へ発展さ せ, 食物繊維の豊富な穀物の摂取の重要性を再認識し, 食生活の改善の一助となればと考えている。

\section{謝辞}

本研究の成果は, 恩師である千葉大学名誉教授・綾 野雄幸先生, 同大学大学院教授 - 真田宏夫先生, 大妻 女子大学教授・池上幸江先生をはじめとする共同研究 者の諸先生, 雪印乳業株式会社技術研究所ならびにサ ッポロビール株式会社の研究員の皆様方による多大な ご指導・ご協力のもとに得られたものである。ここに 感謝申し上げます。

\section{文献}

1）健康・栄養情報研究会編：国民健康・栄養の現状 一平成 17 年厚生労働省国民健康・栄養調查報告より一, pp.66-67（2008）第一出版, 東京

2）池上幸江 : 日本人の食物瀻維摂取量の変遷, 日本 食物繊維研究会誌，1，3-12（1997）

3）柳沢文正, 小笠原公: 強化精麦の生化学的研究 （1）米・麦摂取の血糖値に及ぼす影響, 栄養と食糧, 19, 46-49 (1966)

4）佐藤寿一, 大沢 功, 服部温子, 押田芳治, 佐藤 祐造：食物瀻維の糖代謝に及ぼす影響一健常者及び糖 尿病患者を対象として一, 総合保健体育科学, 13, 7578 (1990)

5）池上幸江, 土橋文江, 中村カホル, 印南 敏: ラ ットにおける実験的糖尿病に対する大麦の効果, 日本 栄盖・食糧学会誌，44，447-454（1991） 
6）小田泰士，青江誠一郎，真田宏夫，綾野雄幸：才 ーツガム質ならびに大麦ガム質の摂取が遺伝性肥満なら びに正常 Zucker ラットの血漿および肝臓脂質濃度に及 ぼす影響，日本栄養・食糧学会誌，44，455-460（1991）

7）小田泰士, 青江誠一郎, 真田宏夫, 綾野雄幸 : ラ ットの脂質代謝に及ぼすオーツガム質ならびに大麦ガム 質の影響, 日本栄養・食糧学会誌，46，147-153（1993）

8) Oda, T., Aoe, S., Sanada, H. and Ayano, Y. : Effects of soluble and insoluble fiber preparations isolated from oat, barley, and wheat on liver cholesterol accumulation in cholesterol-fed rats, J. Nutr. Sci. Vitaminol., 39, 73-79 (1993)

9）青江誠一郎，板垣康治，畑本二美，石井恵子，小 田泰士，鈴木 豊，鳥羽保宏，藤田 孝，木下さと子， 内田俊昭, 竹原 功, 近藤 敦: オートミール含有ク ッキーの摂取が境界域および軽度高コレステロール血 症の日本人男性の血清コレステロール值に及ぼす影 響：有効性と安全性の検討, 日本食物緎維研究会誌, 7 , 26-38（2003）

10）鳥羽保宏, 畑本二美，木下さと子, 内田俊昭, 小田泰士，石井恵子，青江誠一郎，鈴木 豊，藤田 孝, 辻 秀一：オートミール继の摂取が境界域および 軽度高コレステロール血症の日本人男性の血清コレス テロール值に及ぼす影響：有効性と安全性の検討，食 物繊維研究会誌, 7, 71-79（2003）

11) Ripsin, C. M., Keenan, J. M., Jacobs, Jr. D. R., Elmer, P. J., Welch, R. R., Van Horn, L., Liu, K., Turnbull, W. H., Thye, F. W., Kestin, M., Hegsted, M., Davidson, D. M., Davidson, M. H., Dugan, L. D., Denmark-Wahnefried, W. and Beling, S. : Oat products and lipid lowering, JAMA, 267, 3317-3325 (1992)

12）青江誠一郎，藤田 孝，木下さと子，内田俊昭, 須栗紀子, 鳥羽保宏, 辻 秀一, 平形道人, 大矢 清：オートミール悚の摂取が境界域および軽度高コレ ステロール血症者の血清コレステロール值に及ぼす影 響, 栄養学雑誌，64，77-86（2006）
13) Davidson, M. H., Dugan, L. D., Burns, J. H., Bova, J., Story, K. and Drennan, K. B. : The hypocholesterolemic effects of $\beta$-glucan in oatmeal and oat bran, JAMA, 265, 1833-1839 (1991)

14) Anderson, J. W., Gilinsky, N. H., Deakins, D. A., Smith, S. F., O’ Neal, D. S., Dillon, D. W. and Oeltgen, P. R. : Lipid responses of hypercholesterolemic men to oat-bran and wheat-bran intake, Am. J. Clin. Nutr., 54, 678-683 (1991)

15) Poulter, N., Chang, C. L., Cuff, A., Poulter, C., Sever, P. and Thom, S. : Lipid profiles after the daily consumption of an oat-based cereal, Am. J .Clin. Nutr., 59, 66-69 (1994)

16) Whyte, J. L., McArthur, R., Topping, D. and Nestel, P. : Oat bran lowers plasma cholesterol levels in mildly hypercholesterolemic men, J. Am. Diet. Assoc., 92, 446-449 (1992)

17) Judd, P. A. and Truswell, A. S. : The effect of rolled oats on blood lipids and fecal steroid excretion in man, Am. J. Clin. Nutr., 34, 2061-2067 (1981)

18) Lia, Å., Hallmans, G., Sandberg, A.S., Sandburg, B., Åman, P. and Andersson, H. : Oat $\beta$-glucan increases bile acid excretion and a fiber-rich barley fraction increases cholesterol excretion in ileostomy subjects, Am. J. Clin. Nutr., 62, 1245-1251（1995）

19) Anderson, J. W. and Chen, W. L. : Cholesterollowering properties of oat products, Oats, Chemistry and Technology/Webster, F.H. ed., pp.309-333 (1986) The American Association of Cereal Chemists, Inc., St. Paul

20) Shimizu, C., Kihara, M., Aoe, S., Araki, S., Ito, K., Hayashi, K., Watari, J., Sakata, Y. and Ikegami, S. : Effect of high $\beta$-glucan barley on serum cholesterol concentrations and visceral fat area in Japanese men-a randomized, double-blinded, placebo-controlled trial, Plant Foods Hum. Nutr., 63, 21-25 (2008) 